\title{
Interpartner Legitimacy Effects on Cluster Initiative Formation and Development Processes
}

\section{Anna Emmoth, Sabine Gebert Persson \& Heléne Lundberg}

To cite this article: Anna Emmoth, Sabine Gebert Persson \& Heléne Lundberg (2015) Interpartner Legitimacy Effects on Cluster Initiative Formation and Development Processes, European Planning Studies, 23:5, 892-908, DOI: 10.1080/09654313.2014.891567

To link to this article: https://doi.org/10.1080/09654313.2014.891567

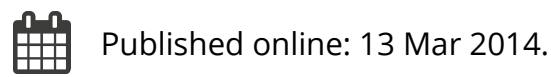

Submit your article to this journal $\pi$

LII Article views: 229

Q View related articles $\sqsubset$

View Crossmark data

4 Citing articles: 6 View citing articles 


\title{
Interpartner Legitimacy Effects on Cluster Initiative Formation and Development Processes
}

\author{
ANNA EMMOTH*, SABINE GEBERT PERSSON** \& \\ HELÉNE LUNDBERG**
}

${ }^{*}$ School of Technology and Business Studies, Dalarna University, Falun, Sweden, ${ }^{* *}$ CER, Mid Sweden University, Sundsvall, Sweden

(Received September 2013; accepted February 2014)

\begin{abstract}
In spite of the growing interest in cluster initiatives (CIs) as a means of regional development, there are still few studies of CIs that offer an inside perspective. This article takes such an inside perspective, focusing on the internal legitimacy aspects of the formation and evolving processes of CIs. We propose the inclusion of interpartner legitimacy effects in order to better understand the formation and development of CIs. A case study method is applied on a Swedish CI in the tourism industry. Faced with the situation that their region was lagging behind other Swedish regions in the development of tourism, the actors were spurred to promote a CI. Its central purposes were to consolidate the regional tourism industry, strengthen the regional brand and to establish the entire region as a single coherent destination. This paper contributes to the research body of regional development and CIs by showing how different types of interpartner legitimacies hinder and facilitate the CI process.
\end{abstract}

\section{Introduction}

Clusters have been emphasized within research since the early 1990s through Porter's work (Porter, 1990) and have since gained increasing attention (cf. Lundequist \& Power, 2002; Malmberg \& Maskell, 2002). Clusters have also been recognized as important for regional development among supra-national bodies, e.g. the World Bank, the Organisation for Economic Co-operation and Development (OECD) and the EU, as well as among national and regional governments and agencies. Prosperous clusters such as the Silicon Valley in California and Third Italy (Saxenian, 1994; Scott, 1988) have come to serve as role models and sources of inspiration (Lundequist \& Power, 2002).

Correspondence Address: Sabine Gebert Persson, CER, Mid Sweden University, Sundsvall 851 70, Sweden. Email: sabine.gebert-persson@miun.se 
The reason for this interest in clusters is their contribution to regional development by means of increased competitive advantage, mainly ascribed to personal relationships, faceto-face communication and interaction among networks of individuals, firms or institutions (Porter, 1998). As a result, actors engaged in regional development take measures to promote cluster-like conditions by designing and promoting collaboration between different sectors, such as firms, government agencies and academic institutions. These types of initiatives, often denoted cluster initiatives (CIs) are designed collaboration initiatives, with the purpose of growing clusters (Sölvell et al., 2003; Teigland \& Lindqvist, 2007; Waxell \& Malmberg, 2007) and fostering networks among people and firms (Sölvell et al., 2003). There is strong support within research for the role of CIs in regional development (Boekholt \& Thuriaux, 1999; Laur et al., 2012; Lundberg \& Andresen, 2012; Sölvell, 2009; Teigland \& Lindqvist, 2007).

Nevertheless, there is still a lack of knowledge on the formation and development of CI processes. In their research on strategic alliances Kumar and Das (2007) argued that it is central to include internal legitimacy negotiation processes regarding goals, rules and norms, called interpartner legitimacy, in order to understand the processes in the formation of strategic alliances. Furthering the arguments of Kumar and Das (2007), Gebert Persson et al. (2011) highlighted the processes of internal negotiation and interpartner legitimacy in explaining network formation processes. Interpartner legitimacy is the "acceptance of an organization by its internal constituencies" (Gebert Persson et al., 2011, p. 1024), i.e. a mutual agreement between members in a network on what actions are perceived as proper and appropriate within that context. As further research is needed on CIs, which to some extent resemble both networks and strategic alliances, we argue that interpartner legitimacy could be used in order to further develop an understanding of the creation and development processes of CIs.

\section{CIs and Tourism}

The aims of CIs are often vaguely formulated by the initiator(s) in order to appeal to a variety of organizations with differing interests, but basically the aim is to develop cooperative relationships among the member organizations (Lundberg, 2008). Typically, CIs tend to have several parallel objectives (Sölvell, 2008). The formation of relationships and common aims are often only a vision in the beginning as the members join a strategically designed network and not one based on naturally evolved relationships. Reasons for participating in CIs might therefore vary between actors (Van Der Sijde et al., 2011) and the initiative may even include actors competing for the same resources and customers (Porter, 2000). In sum, this implies that the members will need time and have to make an effort to find common ground and to identify shared goals. As a consequence, in order for the interaction to gain momentum, a facilitator (a group or a single person) is often appointed and given the tasks of coordination and initiation of joint activities (Lundberg, 2008; Sölvell et al., 2003; Teigland \& Lindqvist, 2007). CI members are usually unwilling to fund or take on this facilitating role themselves at an early stage when the potential gains from participating remain distant and often fairly vague. Therefore, CIs tend to need financial support from public sources in order to get started. Once established, CIs can receive financial support from membership fees and from the sale of different services (Teigland \& Lindqvist, 2007; Sölvell et al., 2003). 
The tourism industry is typically dominated by small and micro-scale businesses operating in a spatial framing often reliant on zero-priced public goods. There are, furthermore, a great number of secondary actors taking an interest in the development of this industry, e.g. the public sector which takes part both as an involved actor and as a sponsor. The tourism product is depicted as a composite product marketed jointly on a destination level (Smith, 1994). Such joint marketing, however, requires bringing actors, both private and public, together in heterogeneous networks. The processes of destination management, market sensing, information sharing and the planning and delivery of tourism products, require considerable and complex interactions (Buhalis, 2000; Fyall \& Garrod, 2005). In 1995, Jamal and Getz introduced their article on inter-organizational collaboration in the tourism industry by stating: "The lack of coordination and cohesion within the highly fragmented industry is a well-known problem to destination planners and managers" (p. 186). More than 10 years later, Dredge (2006) concluded that there has been a shift within tourism towards a development of networks as enablers of innovation and community capacity builders, but that this is still an area that needs further research. We acknowledge this and will contribute to the field by focusing our study on the formation and development of such a network initiative within the tourism industry.

Next, we present three aspects of interpartner legitimacy and how they relate to two stages of network development. We then introduce the chosen method of study, followed by a presentation of the case, our analysis and finally findings and managerial implications.

\section{Interpartner Legitimacy in Two Stages of the CI Process}

Legitimacy has been emphasized as vital for organizations' survival (cf. Human \& Provan, 2000; Sharma, 1991) and is defined as stakeholders' perceptions of an organization's actions as being "[ ... ] desirable, proper, or appropriate within some socially constructed system of norms, values, beliefs, and definitions" (Suchman, 1995, p. 574). Legitimacy is formed independently, and to a varying extent, by different constituents based on their degree of acceptance of perceived behaviour, but it is also something that an actor can influence through different strategies (Ashforth \& Gibbs, 1990; Pfeffer \& Salancik, 1978). Several researchers point to the need for making a distinction between external and internal legitimacies (cf. Bitekine, 2011; Drori \& Honig, 2013; Kostova \& Roth, 2002; Kostova \& Zaheer, 1999). External legitimacy refers to "exogenously determined legitimacy-the acceptance and validation by external stakeholders [...]" (Drori \& Honig, 2013, p. 346), meaning that legitimacy is rendered by stakeholders outside the organization. In contrast, internal legitimacy is "the acceptance or normative validation of an organizational strategy through the consensus of its participants, which acts as a tool that reinforces organizational practices and mobilizes organizational members around a common ethical, strategic or ideological vision" (Drori \& Honig, 2013, p. 347).

Internal legitimacy is thus the members' perceptions of accepted behaviours within a defined group. Kumar and Das (2007) argue that internal legitimacy as a concept ought to be particularly relevant to consider when studying strategic alliances as it deals with how the alliance partners perceive each other, which in turn affects the evolving process of the strategic alliance. As Kumar and Das (2007) highlight, viewing legitimacy as a perception formed by external stakeholders does not capture the complexity of the sometimes deviating expectations on behaviour that can exist for cooperating organizations such as strategic alliances or CIs. A CI needs to gain external legitimacy to be 
accepted by external stakeholders, but also legitimacy within the respective member organizations.

Further complicating the legitimating issue is that within these types of initiatives, competition and cooperation often co-exist, implying that members can have hidden agendas. In order for the $\mathrm{CI}$ to function it is thus central to establish the behaviours that are to be considered accepted and legitimate within the CI. This type of legitimacy is called interpartner legitimacy. With a mutual agreement on accepted behaviour, the members will perceive a low risk of other members acting only in their own interests, i.e. the members will expect actions in line with established norms.

Developing interpartner legitimacy can thus be defined as developing a shared value system among the members. As the CI consists of representatives of different member organizations it is not only necessary that the members perceive each other's actions as proper and appropriate, but also that the representatives have sufficient authority from their own organizations to act and to make decisions.

In an organically developed network, the relationships are formed over time as shared norms and rules develop. In contrast, in a CI one or several actors take the initiative of forming a network by inviting a number of other actors to participate for a common good. As a consequence, the aims of CIs are often fuzzy in order to appeal to a large number of actors (Lundberg, 2008), and there is a risk that members bring in latent knowledge on the nature of tasks, i.e. how to handle the interface with partners. The larger the discrepancies in latent knowledge are, the higher the risk of problems in coordinating activities (Kumar \& Das, 2007).

\section{Pragmatic, Moral and Cognitive Interpartner Legitimacy}

Fuzzy aims and differences in latent knowledge are two factors complicating the evolving formation of the CI. Another factor affecting cooperation is that the member organizations bring in a priori expectations on the effects on efficiency and equity of CI participation. The higher the probability of positive expectations coming true, the more committed the members will be towards the CI. If the CI meets the expectations of return on equity and efficiency, it will be perceived as having pragmatic interpartner legitimacy and the member organization will recognize the cooperation within the CI network as a means to reach better results. For this to be attained it is considered essential that the members can agree on proper behaviours within that context-in other words, reach moral interpartner legitimacy. This type of legitimacy is based on normative evaluations of whether a member's behaviour within the network is appropriate. (Gebert Persson et al., 2011). Finally, given that the members identify advantages of the cooperation and the behaviours of the other members are perceived as having moral interpartner legitimacy, participation in the CI will be taken for granted and cognitive interpartner legitimacy will be reached. (Kumar \& Das, 2007)

Interpartner legitimacy in a CI formation and development process is not static; it evolves and changes over time where the different types of interpartner legitimacy may play different roles at different stages. In order to understand the dynamics, we adopt the framework by Kumar and Das (2007). Their discussion concerns organically developed strategic alliances, but the suggested development stages: formation, operation and outcome, can be considered generic. In these stages, the three types of interpartner legitimacy have different levels of importance in the process. However, CI members 
are generally likely to start from lower levels of interpartner legitimacy than members of strategic alliances since the former are designed and have rather vague purposes to begin with whereas the latter are organically (bottom-up) developed and have a more specific business purpose. In both cases, nevertheless, interpartner legitimacy is a key to success. In the following, we focus on the first two stages, the formation and operation stages.

In the formation stage the $\mathrm{CI}$ is initiated where discussion on the role, aim, norms and rules of behaviours of the CI need to be settled. During this stage, the pragmatic interpartner legitimacy is most critical as the members need to agree on the mutual benefits of the CI. Pragmatic interpartner legitimacy will fail if benefits of cooperating within the CI are lacking and thus also the reasons for the individual members to be members of the CI. The members need to agree on a number of issues which will be more complicated in cases where there is no or little prior history of interaction between the actors, and/or when there is high uncertainty about the possibilities of achieving positive outcomes by working within the CI. In addition, negotiations are hampered when members are potential competitors, since they may be reluctant to share information and be sensitive to potential partner opportunism (Das \& Kumar, 2011). It therefore becomes of central importance for a CI facilitator to allay the uncertainties of the members so that pragmatic legitimacy can be attained (Kumar \& Das, 2007). Moral interpartner legitimacy will also be affected by the formation process as it is dependent on how the members negotiate with each other. The behaviour at this stage will form expectations of, and set the platform for, how the members behave in the following stages.

When the CI has been formed, the operation stage follows and implementation of the agreements is in focus. Interpartner negotiations will at this stage concern new opportunities, but there will also be a need for resolution of conflicts arising from partner interactions (Das \& Kumar, 2011). The moral and the cognitive interpartner legitimacy become more critical for the CI than the pragmatic interpartner legitimacy. The members need to rely on each other and behave in accordance with the established agreements for proper behaviour (i.e. the moral interpartner legitimacy). A high level of moral interpartner legitimacy is central to a high degree of commitment among the members and will depend on whether the members are perceived to behave in an accepted manner or not. If a member acts in an unacceptable way according to the CI agreements on proper and appropriate behaviour, the other members may either start questioning the whole logic of the CI (the cognitive interpartner legitimacy) or become more cautious as to what information they are sharing. It is important that the CI is recognized as being of strategic importance for the member organizations as they will otherwise not keep investing resources and develop activities to keep and develop the CI. At the operation stage it is therefore critical that the member organizations perform in line with their commitments (moral interpartner legitimacy).

\section{Method}

In order to capture the formation of the tourism destination network, how the CI development process was perceived by the organizers and how it evolved, a case study method was chosen. It is a recommended research approach when the studied process is of an explorative and longitudinal character and when the boundaries between phenomenon and context are not clearly evident (Yin, 2009). Case studies are also considered suitable for studies of 
network development processes (Halinen \& Törnroos, 2005; Heikkinen et al., 2007). The case was selected due to an excellent opportunity to apply an ethnographic approach for data collection (Denscombe, 2009), since one of the authors was invited to follow the formation process of a CI during a two-year period of time, by attending CI meetings and conducting interviews.

\section{Data Collection}

Ethnographic techniques were applied through member observation. The essence of ethnographic research is that it allows the researcher "to get 'inside the minds' (Curran \& Blackburn, 2001, p. 113) of those being studied to understand the values, meanings, motivations and logics which govern action" (Jack, 2005, p. 1239). One of the authors attended nearly all (12) of the studied CIs strategic meetings during 2010 and 2011. The observations were direct but rather passive, since the researcher took notes and only sparsely participated in the conversations. By attending meetings, the researcher was able to sense the atmosphere within the network and gain a better understanding of how the CI members interacted and collaborated.

In addition interviews and informal conversations were used to understand events and processes from the participants' point of view and to capture the meaning they attach to different happenings. Ethnographic research theorizes that individuals actively shape situations instead of being passive responders to external events, thus the context and behaviour are regarded as being interlinked. Based on this premise, the interviews were conducted in an open manner, based only on a topic guide. Questions were not asked in any specific order, but were governed by the interview situation and the respondents were encouraged to elaborate on emergent themes and ideas (Gummesson, 2000). In total, 14 interviews were conducted in 2010 and 2011 with representatives from every member organization of the CI, together with a number of public officials responsible for regional economic development issues and two consultants. The respondents were interviewed individually and the interviews, which lasted 1 to 3 hours, were all recorded and transcribed. In parallel, there were furthermore several informal conversations with the interview responders and other persons with an interest in the development of the tourism industry on the regional level. Finally, to enforce the validity of the research and to develop a general understanding of the wider context, we studied other sources of evidence, such as official documents, websites and internal documents.

Ethnography allowed us to collect a rich body of contextual information from the case. In order to analyse the data and interpret the process we drew on some basic ideas from the critical incident technique (CIT).

\section{Data Analysis}

CITs were initially defined by Flanagan (1954) as incidents that "occur in a situation where the purpose or intent of the act seems fairly clear to the observer and where its consequences are sufficiently definite to leave little doubt concerning its effects" (p. 327). Today, half a century later, there are many alternative definitions in use and the original method has been redefined and adjusted to qualitative studies of an interpretative character. A general and pragmatic definition is that an incident is critical if it causes significant change (Schurr, 2007), or if it deviates significantly from the respondent's expectations 
(Kaulio \& Uppvall, 2009). The method may be used in process research when the aim is to highlight effective or ineffective approaches, helping or hindering factors, successes and failures, or determine important characteristics (Butterfield et al., 2005).

The CIT method has been used in a variety of fields, such as in studies of communications, nursing, job analysis, education and teaching (Butterfield et al., 2005). CIT has also played a considerable role in the studies of the relationship between customers and service providers within the field of service management and marketing (Edvardsson \& Roos, 2001) with a special emphasis on how service failures have affected those relationships (Schurr, 2007). According to Kaulio and Uppvall (2009), the CIT method is not usually adopted in studies of alliances although it is well suited for that purpose. They stress that the method may not cover all aspects of relevance, but still they claim that the important aspects most likely are covered even if the method is of a retrospective character since the identified incidents actually are perceived as critical, which indicates good recall by the respondents.

According to Chell (2004, p. 47), the CIT method makes it possible "through the process of a largely unstructured interview to capture the thought processes, the frame of reference and the feelings about an incident or set of incidents, which have meaning for the respondent". Data on critical incidents may be collected not just through personal interviews. Observation is a common and often preferred method (Butterfield, et al., 2005).

For the purpose of this study, a critical incident is defined as an identifiable incident (like an event, moment, decision or other type of action) which the respondents perceive as essential for either having pushed the cluster initiative process forward or backward, or having delayed the cluster initiative process. Interviews, informal conversations and observations proved to be a useful complement to each other and it soon became apparent that some incidents in the network process were more noteworthy than others. These incidents were gradually compiled and discussed with respondents during follow-up conversations or interviews. Once the data was sorted, we analysed the critical incidents from an interpartner legitimacy perspective. Every incident was therefore deconstructed and investigated in accordance with the pragmatic, moral and cognitive classifications, as shown later in the discussion section. The distinction between external and internal legitimacies was drawn from the CI's perspective, i.e. all actors except the CI members were considered external.

\section{The Case}

The studied case was the first CI to be initiated in the Swedish tourism industry (Nordensky, 2009). It was established in Dalarna in 2007 by the Regional Development Authorities (RDA) as a publicly funded regional development project. Its central purposes were to consolidate the regional tourism industry, to strengthen the regional brand and to establish the entire region as a single coherent destination. The underlying aims were to increase the competitiveness of companies in the tourism industry and to stimulate regional economic growth. This section of the paper provides an introduction to the case, outlining the background of the $\mathrm{CI}$ and some influential preconditions, followed by an account of the first 4 years of the CI formation process.

Dalarna is a sparsely populated region in central Sweden with approximately the same geographical size as the Netherlands, but with a much smaller population (277,000 compared to 16 million). Dalarna has a long tradition of tourism and is one of the most visited 
regions in Sweden in terms of the number of guest nights. The region has 15 municipalities, divided into five different tourism destinations. ${ }^{1}$ Dalarna's municipalities have transferred responsibility for the strategic planning and marketing of the destinations to specific organizations, labelled destination management organizations (DMOs). The DMOs differ with respect to organizational structure and ownership, but in all cases the municipalities are main principals. In the tourism literature, research calls for a broad involvement and collaboration of diverse actors in tourism networks (cf. Lemmetyinen \& Go, 2005; Murphy, 1988), particularly in the case of destination planning and management (D’Angella \& Go; 2009; Jamal \& Getz, 1995; Keogh, 1990; Sautter \& Leisen, 1999). Within the tourism literature the destination is often a primary unit of study and a frequently cited definition is provided by Buhalis (2000) "destinations are amalgams of tourism products, offering an integrated experience to consumers". We consider destinations as a defined geographical region, understood by its visitors as a unique entity with a political and legislative framework for tourism marketing and planning. Destination management organizations (DMOs) are non-profit organizations with the explicit responsibility of coordinating destination activities in order to attract visitors (Elbe et al., 2009; Gretzel et al., 2006).

Historically, direct cooperation between the destinations in Dalarna had been relatively scarce. Interviews with the DMO managers revealed rather poor experiences of tourism collaboration before the founding of the CI. The five DMOs regarded themselves as competitors to some extent, since they competed for both regional funding and visitors. Moreover, the responsibility of coordinating overall regional tourism development issues has been divided and transferred between organizations and associations, both formal and informal, for decades (one of these associations, with representatives from each of the 15 municipalities and 3 regional bodies, is below referred to as the former regional association). Many actors in the regional tourism arena had long called for a region-wide public body with a decision-making mandate on behalf of all 15 municipalities. However, some DMOs had been dissatisfied with the distribution of regional funds, which caused mistrust towards regional authorities in general regarding their capability to pursue tourism issues.

In 2003, a new organizational construction on the regional level, the RDA, was founded by all the local municipalities together with the County Council. This would prove to be a landmark in the development of the CI for several reasons. First, the founders of the RDA made a strategic decision to place regional tourism-development issues under the auspices of this new public body and to employ a Regional Tourism Manager. Hence the RDA became the region-wide public body with the adequate decision-making mandate that the tourism industry had demanded. Secondly, since local politicians from the 15 municipalities were in the RDA board, they became an important link between the strategic decision-making on the region level and the decision-making and implementation on the local municipality level. As one of the respondent remarked:

The gain of putting the responsibility of these questions on the region was that it resulted in a completely different level of commitment from the municipalities[ . . . ]it has been much easier to push through a decision in my DMO board now when several of my board members have a place on the RDA board as well.

In 2003, when the RDA board made a long-term strategic decision to adopt a "cluster development strategy" with the intent to stimulate regional competitiveness and growth, 
RDA officials, including the recently employed Regional Tourism Manager, started to work on forming a CI within an, in this context, entirely untried industry-the tourism industry.

\section{The CI Formation Process}

In the end of 2006, the RDA obtained a funding approval to develop a tourism CI. It encompassed six representatives: one from each of the five destinations and a facilitator: the Regional Tourism Manager who had the official mission to coordinate regional tourism development issues. The CI formed a completely new forum and the members perceived it as a great opportunity. One respondent stated: "I felt we got a huge chance to actually sit down together, some selected people/ ... /, we sat down with a blank paper and just started to create". Interviews revealed that the former regional association was perceived as more of an informational forum than an executive forum, partly due to the fact that its members had different types of duties, roles and power in their respective municipalities. In contrast, this new network was composed of people with similar duties, roles and power. Four of them were DMO CEOs and the fifth person was the chairman of a business network. Hence the CI members had similar business experience, unlike in the case of the regional association. Furthermore the size of the CI was perceived as another facilitating factor by all members, as they were only 6 members (including the facilitator), instead of 18 in the former regional association.

If 18 people sit together during a break you will disappear, but if five people sit together during a break it is like a handful of people that can really communicate, which makes it a handy little group. And then I feel that we've had a lot of meetings, I mean tight meetings, that somehow have enabled us to grow tighter together.

\section{The Process Slows Down but Change Brings New Energy}

In spite of the initial enthusiasm, the members found it difficult to get started. There was still some uncertainty among the members about the purpose of the $\mathrm{CI}$ and the probability of success and they felt uncomfortable with the "cluster" label, which caused confusion in the group since they did not know what it stood for. Furthermore, one of the members was acting in a protectionist manner, showing no interest in cooperation. The representative in question was eventually replaced by a person with a completely different attitude. This new person had previously participated in successful cooperative projects and was totally convinced that in order to be successful in the international market they had to join forces and create a new coherent destination. With the arrival of this new representative, the group found new energy and the members started to open up to each other, both professionally and personally.

In January 2008, the CI received its second funding approval from the Swedish Agency for Economic and Regional Growth. This was critical for several reasons. It implied a financial base for subsequent activities and served as a door opener to the Swedish National Cluster Program and the meetings they arranged for CIs in Sweden. Moreover, it provided reasons to set up a marketing umbrella with its own network identity. There were also other factors that strengthened the CI formation. One was the result of a survey revealing that the total amount of planned investments in the region until 2020 
was 1 billion Euros, resulting in 35,000 new guest beds and approximately 2200 new jobs. Historically, the tourism industry had had problems competing with other industries for regional funding, but these new investment figures put tourism matters on top of the political agenda in the region. One member said: "I would say that among the politicians in this region it became very trendy to support the development of tourism". The forecast gave new energy to the network because it entailed a joint challenge: to fill the 35,000 beds with new guests.

\section{Engaging a Cluster Coach}

Even though the CI had found a common aim in the challenge of filling 35,000 beds, the members felt that the CI meetings were unorganized and had a rather low participation rate. In order to improve the meeting content and efficiency, a cluster coach was engaged to support the Regional Tourism Manager in the facilitating role. The cluster coach and the members decided on some basic meeting rules regarding attendance and decision-making. During the following autumn, they had several creative all-day meetings together with the cluster coach and identified five potential areas of cooperation.

At this stage they sensed a need to present the CI and its purpose to the regional industry so they arranged a one-day seminar called "Vision Day". The seminar was held in March 2009 and was attended by around 200 people, representing both private and public organizations with a common interest in the development of the regional tourism industry. The activity during the seminar was intense and the CI members agreed that the "Vision Day" was a complete success: "On the Vision Day we as a group obtained a mandate to bring this strategic development into the future and it's a very big and accountable mission";

It felt like it was the milestone where we really received credit for our ideas and that was great of course but above all we got ideas in return that proved to be what we were already working on which even further reinforced the feeling that we had the mandate to continue.

Before the Vision Day took place, none of the CI members had expressed a need for better support and contact with the regional tourism businesses. However, afterwards they all felt that the seminar was decisive because they had all received massive support regarding the $\mathrm{CI}$ formation and the proposed strategic areas of cooperation. The documentation from the seminar discussions was analysed, three of the proposed areas for cooperation were prioritized and a number of projects were initiated.

One of these projects aimed at creating a joint selling-and-booking on-line platform, which in turn demanded that all DMOs were to be integrated into one single distribution system. At the time, the CI lacked a representative from the DMO in Destination 3. To fill the gap they invited the DMO manager who accepted. The CI thus became a homogenous group of five DMO managers and a Regional Tourism Manager.

In December 2009, the CI received a third funding approval from the Swedish Agency for Economic and Regional Growth, which secured the continuation of the project for two more years. Again, this was a prerequisite for subsequent activities as well as a validation of the achievements so far. As the online booking system project began to take off, the discussions became more and more detailed. The network members handled very concrete technical and operational questions during the meetings, but still had not settled on 
the overall purpose for the CI. Some members wanted to focus on the development of an integrated online booking system, while others were more preoccupied with the vision of forming one single coherent destination. Two different tracks running simultaneously proved to be quite a challenge and in the beginning of 2010, two of the members felt that it was time to "pull the brakes" and recapture an overview of the CI and all its activities.

\section{Discussion}

The purpose of this article is to analyse the interpartner legitimacy's influence on the formation and development processes on a network level in CIs within tourism. We propose the inclusion of interpartner legitimacy effects to understand the formation and development of CIs and contribute by showing the interplay between the different interpartner legitimacies and between external legitimacy and interpartner legitimacy in the formation process.

The studied case illustrates a CI formation within the tourism industry in a region composed of five separate destinations. Prior to the CI formation, the destinations regarded themselves as competitors and had almost no history of direct cooperation. Furthermore, there was also initial dissatisfaction among the DMOs concerning the distribution of regional funds. Due to this lack of prior cooperation and existing discontent, the members had a competitive attitude towards each other and there was scepticism among several DMOs regarding the regional authorities' capability to handle tourism development issues and the distribution of funds. This implies that the CI initially showed weak pragmatic interpartner legitimacy. Moreover, the members doubted that the others would act properly according to norms, resulting in low moral interpartner legitimacy as well. The low levels of moral and pragmatic interpartner legitimacy hampered cognitive interpartner legitimacy. With the reorganization at the regional level and by establishing the RDA in the position to build a region wide functioning network, as opposed to the previous loosely connected and informal regional association. The DMOs had long called for a negotiation partner at the regional level and the RDA was perceived to measure up. The confidence in the regional authorities had increased, and so had the pragmatic interpartner legitimacy, resulting in a significantly improved starting position for the CI formation.

The funding approval for a potential tourism CI proved to be the actual starting point of the network formation process. It showed that the idea of setting up a regional tourism CI had external legitimacy, which raised the pragmatic and cognitive interpartner legitimacy as the members started to see potential gains in strengthened relations between destinations. There was a particular increase in the pragmatic interpartner legitimacy when the members realized the opportunity to influence the regional political agenda and the distribution of regional funding, which appealed to their self-interests, i.e. pragmatic legitimacy, and facilitated the CI formation process. Hence, external legitimacy strengthened the pragmatic interpartner legitimacy in the evolution of the CI.

The decision to form the CI and its structure strengthened the moral interpartner legitimacy, since the members regarded themselves as legitimate representatives of the five destinations and the RDA. The small size of the CI, compared to the former alignment of 18 members in the regional association, was another facilitating factor. The CI meant that the DMO managers finally had a meeting venue and the members started to believe 
in the likelihood of building a strategic and productive collaboration between destinations. This indicates that members started to build up moral interpartner legitimacy at this stage of the process. However, the CI faced some initial difficulties, partly due to an uncertainty among the members regarding its purpose, which was so vague and abstract that they found it problematic to explain the CI's intentions to their shareholders or member companies. They also had problems understanding the concept of "cluster" and "CI" and explaining why they suddenly were a tourism cluster, which caused further problems in their communication with different stakeholders. This reveals initial problems with the pragmatic interpartner legitimacy. The difficulties can also partly be attributed to the protectionist behaviour of one of the members, causing confusion in the group and reinforced the scepticism about the benefits of CI participation, implying decreased pragmatic and cognitive interpartner legitimacy. When the network representative, who was perceived as protectionist, was replaced by a person with a completely different approach, the climate within the network turned more positive and encouraging, which was a turnaround for the development of all three forms of interpartner legitimacy.

The second funding approval in January 2008 was another critical incident. The support from the national level not only provided financial means, but once again it was evidence of the CI's external legitimacy, which reinforced the members' conception of being part of a promising initiative. Moreover, the funding approval qualified the CI to become part of the national cluster programme, which further strengthened their status as a cluster. The increased external legitimacy once again increased the pragmatic legitimacy and in turn also the cognitive interpartner legitimacy. The positive forecast on future investments in the tourism sector also increased the pragmatic interpartner legitimacy as the group could agree on a common goal to expand into foreign markets and to act collectively.

Although the CI had gained momentum there were still issues with pragmatic and moral legitimacy. As a result of a series of all-day meetings led by the cluster coach, the network managed to identify five potential areas of cooperation. This conformity was a necessary step in the legitimacy process, as it radically increased the pragmatic interpartner legitimacy and thereby also increased the cognitive interpartner legitimacy. The members had finally found some concrete purpose for the CI, which facilitated their communication towards external actors, such as member companies of the DMOs.

The Vision Day was another critical incident which reinforced the CI's external legitimacy. The members experienced support from the tourism businesses both regarding the $\mathrm{CI}$ as such and the proposed strategic areas of cooperation. The support of the CI as such strengthened the members' confidence in the rationale of the network as well as their perception of participation incentives, which increased the cognitive interpartner legitimacy. Similarly, the support of the areas of cooperation raised the interpartner legitimacy giving the CI momentum to begin a number of projects. One of the projects required representation from all five DMOs for organizational reasons. When the fifth DMO manager entered the group it resulted in a very homogenous group, which added to the moral interpartner legitimacy as they perceived that they could more easily predict the behaviour of the other members, and shared a similar organizational and business context. This further strengthened the evolution of the CI.

The CI received another approval for funding in December 2009. This sanctioning of the CI from the national level was of great importance. It not only provided financial means, but also reinforced that the members perceived the external legitimacy of the $\mathrm{CI}$, which further strengthened the cognitive interpartner legitimacy. 
In the beginning of 2010, several projects and activities had been launched and outwardly it seemed that the CI had developed smoothly, but the experience within the network was inconsistent. An increasing number of projects and processes were running simultaneously and finally the members did not manage to get a clear picture of the whole. Additionally, the different priorities among members led to conflicts. Two of the members regarded the situation as troublesome and confusing enough to "put the brakes on". This shows that the legitimacy-development process is not a linear one, which also affects the CI formation process. New events can both strengthen and weaken moral, pragmatic and cognitive interpartner legitimacy. Furthermore, the different types of interpartner legitimacy may develop in divergent directions. This was the case in 2010 when pragmatic interpartner legitimacy increased as many different opportunities were discovered and acted upon. At the same time, the priorities of the different opportunities created fragmentation among the members, resulting in decreasing moral and cognitive interpartner legitimacy. There was thus an increase of pragmatic interpartner legitimacy but the side-effect was a decrease in the other two interpartner legitimacies.

\section{Findings and Main Contributions}

Inter-organizational cooperation has been shown to increase the "collective legitimacy" of the industry as such (Sharfman et al., 1991 in Dacin et al., 2007). However, this case illuminates that in order to reach this stage, interpartner legitimacy has to be considered. We argue that interpartner legitimacy has to be incorporated into the analytical model if we wish to understand the processes of negotiations on the rules and norms that set the future possibilities for multi-actor interactions such as the formation and development of CIs.

The case highlights the complexity of being embedded in different network contexts at different levels, resulting in actors being involved in different institutional settings such as the CI, the destination and their own organization, all with different legitimacy pressures. The five DMOs had to take the wishes of all their stakeholders into account: namely the local residents, the local businesses, visitors, business partners and shareholding municipalities. This implies an intractable complexity which makes the legitimacy-development process challenging and time consuming. This paper contributes to the research on regional development and CIs by showing how different types of interpartner legitimacies hinder and facilitate the CI process. Increasing pragmatic, moral and cognitive interpartner legitimacy strengthened the network process whereas decreasing pragmatic, moral and cognitive interpartner legitimacy harmed the network process. Finally, it seems that while pragmatic and moral interpartner legitimacy may develop independently, the outcome in terms of cognitive interpartner legitimacy is dependent on the development of pragmatic and moral interpartner legitimacy both jointly and separately. An increase in or decrease of pragmatic and/or moral interpartner legitimacy will influence cognitive interpartner legitimacy in the same direction. However, it seems unlikely that a shared high level of cognitive legitimacy can be reached unless both pragmatic and moral interpartner legitimacy are at a high level as well, which is in line with Kumar and Das' (2007) arguments. It is also likely that in most cases fairly high levels of both pragmatic and moral interpartner legitimacy have to be reached before cognitive interpartner legitimacy starts to develop. 
Nevertheless, it is important to notice that the replacement of one of the network members had a major impact on both pragmatic and moral interpartner legitimacy. In other words, not only the participating organizations as such but also the individuals representing those organizations have an impact on interpartner legitimacy and thereby on the development of inter-organizational network cooperation.

Furthermore, for the new representative, the cognitive interpartner legitimacy was high from the start as a result of previous positive experiences of inter-organizational cooperation. She was totally convinced that inter-organizational cooperation was the best way forward and did not question the CI idea. This impact of the learning effect of networking (Dacin et al., 2007) on interpartner legitimacy has previously not been fully noticed. It is a noteworthy exception from the proposition by Kumar and Das (2007) that cognitive interpartner legitimacy usually becomes evident during the late stages of CI development. Another area of interest is the parallel processes that could be observed in this case. Different members came to be involved in different projects and aims, e.g. the development of the integrated online booking system that came to be put against the parallel work of creating the vision to form one single destination. This indicates that there were structural issues in the CI, which created parallel processes and thereby competition for the resources within the network. Hence the structure of the CI created conflicts of interest which reduced the interpartner legitimacy.

It is also shown that the interplay between the external legitimacy markedly affected the interpartner legitimacy. In the case there were several examples of how increased external legitimacy, such as positive feed-back on their work from public bodies or the companies and organizations they represented, positively affected interpartner legitimacy. It can accordingly be assumed that reduced external legitimacy would affect interpartner legitimacy. If outsiders were to question their performance, the CI members might react by intensifying their efforts to succeed or come to doubt the cause themselves. Finally, it is likely that a lack of interpartner legitimacy will markedly reduce external legitimacy whereas high interpartner legitimacy would pave the way for high external legitimacy. A project that cannot gain the support of its members is unlikely to obtain external legitimacy whereas high interpartner legitimacy is likely to improve the work and thereby increase external legitimacy. In sum, both internal factors and external, contextual factors need to be taken into account when addressing interpartner legitimacy issues. It would further the process of understanding interpartner legitimacy's effect on network formations if research would develop the concepts of internal and external legitimacy and study their interplay even further than was done within this paper.

\section{Managerial Implications}

This paper argues that it is important to consider interpartner legitimacy in CI formation and development processes. It implies that managers involved in the tourism industry who are considering the formation of a CI need to consider not only what resources and activities could be created through the CI but also how the necessary cooperation can be achieved by creating platforms that facilitate the development of interpartner legitimacy. Shared high-value goals must be agreed upon so that pragmatic interpartner legitimacy develops and CI members must discuss and agree upon a code of conduct, so that moral interpartner legitimacy increases. Only then can the perceived legitimacy of the $\mathrm{CI}$ as a whole, the cognitive interpartner legitimacy, develop as well. In addressing the 
legitimacy issue, the impact of external legitimacy also has to be considered since the degree of external legitimacy achieved and communicated will affect the development of internal interpartner legitimacy. In other words, exposing a CI to benevolent external audiences will increase the degree of external legitimacy communicated to the CI members and thereby positively affect the development of interpartner legitimacy. If, on the other hand, interpartner legitimacy is lacking, it will impede creating a CI where the members trust each other and are committed to the network's aims.

\section{Note}

1. At the studied period of time, there were five destinations, but in the beginning of 2012 two of the destinations have merged to one.

\section{References}

Ashforth, B. E. \& Gibbs, B. W. (1990) The double-edge of organizational legitimation, Organization Science, $1(2)$, pp. $177-194$.

Bitektine, A. (2011) Toward a theory of social judgments of organizations: The case of legitimacy reputation and status, Academy of Management Review, 36(1), pp. 151-179.

Boekholt, P. \& Thuriaux, B. (1999) Public policies to facilitate clusters: Background, rationale and policy practices in international perspective, in: Organisation for Economic Co-operation and Development (Ed.) OECD report: Boosting Innovation: The Cluster Approach, pp. 381-412 (Paris: OECD).

Buhalis, D. (2000) Marketing the competitive destination of the future, Tourism Management, 21(1), pp. $97-116$.

Butterfield, L. D., Borgen, W. A., Amundson, N. E. \& Maglio, A-S. T. (2005) Fifty years of the critical incident technique: 1954-2004 and beyond, Qualitative Research, 5(4), pp. 475-497.

Chell, E. (2004) Critical incident technique, in: C. Cassell \& G. Symon (Eds) Essential Guide to Qualitative Methods in Organizational Research, pp. 45-60 (London: Sage).

Curran, J. \& Blackburn, R. A. (2001) Researching the Small Enterprise, (London: Sage).

Dacin, M. T., Oliver, C. \& Roy, J.-P. (2007) The legitimacy of strategic alliances: An institutional perspective, Strategic Management Journal, 28(2), pp. 169-187.

D'Angella, F. \& Go, F. (2009) Tale of two cities' collaborative tourism marketing: Towards a theory of destination stakeholder assessment, Tourism Management, 30(3), pp. 429-440.

Das, T. K. \& Kumar, R. (2011) Interpartner negotiations in alliances: A strategic framework, Management Decision, 49(8), pp. 1235-1256.

Denscombe, M. (2009) Forskningshandboken - för småskaliga forskningsprojekt inom samhällsvetenskaperna, (Lund: Studentlitteratur).

Dredge, D. (2006) Policy networks and the local organisation of tourism, Tourism Management, 27(2), pp. 269-280.

Drori, I. \& Honig, B. (2013) A process model of internal and external legitimacy, Organization Studies, 34(3), pp. 345-367.

Edvardsson, B. \& Roos, I. (2001) Critical incident techniques: Towards a framework for analyzing the criticality of critical incidents, International Journal of Service Industry Management, 12(3), pp. 251-268.

Elbe, J., Hallén, L. \& Axelsson, B. (2009) The destination-management organisation and the integrative destination-marketing process, International Journal of Tourism Research, 11(3), pp. 283-296.

Flanagan, J. C. (1954) The critical incident technique, Psychological Bulletin, 51(4), pp. 327-358.

Fyall, A. \& Garrod, B. (2005) Tourism Marketing: A Collaborative Approach, (Clevedon: Channel View Publications).

Gebert Persson, S., Lundberg, H. \& Andresen, E. (2011) Interpartner legitimacy in regional strategic networks, Industrial Marketing Management, 40(6), pp. 1024-1031.

Gretzel, U., Fesenmaier, D., Formica, S. \& O'Leary, J. (2006) Searching for the future: Challenges faced by destination marketing organizations, Journal of Travel Research, 45(2), pp. 116-126.

Gummesson, E. (2000) Qualitative Methods in Management Research, (Thousand Oaks, CA: Sage). 
Halinen, A. \& Törnroos, J.- $\AA$. (2005) Using case methods in the study of contemporary business networks, Journal of Business Research, 58(9), pp. 1285-1297.

Heikkinen, M. T., Mainela, T., Still, J. \& Tähtinen, J. (2007) Roles for managing in mobile service development nets, Industrial Marketing Management, 36(7), pp. 909-925.

Human, S. E. \& Provan, K. G. (2000) Legitimacy building in the evolution of small-firm multilateral networks: A comparative study of success and demise, Administrative Science Quarterly, 45(2), pp. 327-365.

Jack, L. S. (2005) The role, use and activation of strong and weak network ties: A qualitative analysis, Journal of Management Studies, 45(6), pp. 1233-1259.

Jamal, T. \& Getz, D. (1995) Collaboration theory and community tourism planning, Annals of Tourism Research, 22(1), pp. 186-204.

Kaulio, M. \& Uppvall, L. (2009) Critical incidents in R\&D alliances: Uncovering leadership roles, European Management Review, 6(3), pp. 195-205.

Keogh, B. (1990) Public participation in community tourism planning, Annals of Tourism Research, 17(2), pp. 449-465.

Kostova, T. \& Roth, K. (2002) Adoption of an organizational practice by subsidiaries of multinational corporations: Institutional and relational effects, Academy of Management Journal, 45(1), pp. 215-233.

Kostova, T. \& Zaheer, S. (1999) Organizaitonal legitimacy under conditions of complexity: The case of the multinational enterprise, Academy of Management Review, 24(1), pp. 64-81.

Kumar, R. \& Das, T. K. (2007) Interpartner legitimacy in the alliance development process, Journal of Management Studies, 44(8), pp. 1425-1453.

Laur, I., Klofsten, M. \& Bienkowska, D. (2012) Catching regional development dreams: A study of cluster initiatives as intermediaries, European Planning Studies, 20(11), pp. 1909-1921.

Lemmetyinen, A. \& Go, F. (2005) The challenge of coordinating connectedness amongst different stakeholders in dispersed networks: The case of Finnish tourism enterprises. Paper presented at IMP Conference, Erasmus University, Rotterdam.

Lundberg, H. (2008) Geographical proximity effects and regional strategic networks, PhD dissertation. No. 135, Department of Business Studies, Uppsala University, Uppsala.

Lundberg, H. \& Andresen, E. (2012) Cooperation among companies, universities and local government in a Swedish context, Industrial Marketing Management, 41(3), pp. 429-437.

Lundequist, P. \& Power, D. (2002) Putting porter into practice? Practices of regional cluster building: Evidence from Sweden, European Planning Studies, 10(6), pp. 685-704.

Malmberg, A. \& Maskell, P. (2002) The elusive concept of localization economies: Towards a knowledge-based theory of spatial clustering, Environment and Planning, 34(3), pp. 429-449.

Murphy, P. (1988) Community driven tourism planning, Tourism Management, 9(2), pp. 96-104.

Nordensky, J. (2009) Kartläggning av Svenska Klusterinitiativ, Vinnova Rapport VR 2009:31 (Stockholm: Vinnova).

Pfeffer, J. \& Salancik, G. R. (1978) The External Control of Organizations: A Resource Dependence Perspective, (New York: Harper \& Row).

Porter, M. (1990) The Competitive Advantage of Nations, (New York: The Free Press).

Porter, M. (1998) Clusters and the new economics of competition, Harvard Business Review, NovemberDecempber 1998.

Porter, M. (2000) Location, competition, and economic development: Local clusters in a global economy, Economic Development Quarterly, 14(1), pp. 15-35.

Sautter, E. \& Leisen, B. (1999) Managing stakeholders, Annals of Tourism Research, 26(2), pp. 312-328.

Saxenian, A. (1994) Regional Advantage: Culture and Competition in Silicon Valley and Route 128, (Cambridge, MA: Harvard University Press).

Schurr, P. H. (2007) Buyer-seller relationship development episodes: Theories and methods, Journal of Business \& Industrial Marketing, 22(3), pp. 161-170.

Scott, A. J. (1988) Flexible production systems and regional development: The rise of new industrial spaces in North America and Western Europe, International Journal of Urban and Regional Research, 12(2), pp. $171-186$.

Sharfman, M. P., Gray, B. \& Yan, A. (1991) The context of interorganizational collaboration in the garment industry: An institutional perspective, The Journal of Applied Behavioral Science, 27(2), pp. 181-208.

Sharma, D. D. (1991) International Operations of Professional Firms, (Lund: Studentlitteratur).

Smith, S. (1994) The tourism product, Annals of Tourism Research, 21(3), pp. 582-595. 


\section{A. Emmoth et al.}

Sölvell, Ö. (2009) Clusters - Balancing Evolutionary and Constructive Forces, (Stockholm: Ivory Tower Publisher).

Sölvell, Ö., Lindqvist, G. \& Ketels, C. (2003) The Cluster Initiative Greenbook, (Stockholm: Ivory Tower Publisher)

Suchman, M. C. (1995) Managing legitimacy: Strategic and institutional approaches, Academy of Management Review, 20(3), pp. 571-610.

Teigland, R. \& Lindqvist, G. (2007) Seeing eye-to-eye: How do public and private sector views of a biothech cluster and its cluster initiative differ? European Planning Studies, 15(6), pp. 767-786.

Van Der Sijde, P., Jurjens, P., Pastoor, R., Hiemstra, G. \& Oudshoorn, M. (2011) Acquiring valuable knowledge by organizations: A reversal of the knowledge transfer process. Annual International Conference of High Technology Small Firms, Manchester, UK, June 17-22.

Waxell, A. \& Malmberg, A. (2007) What is global and what is local in knowledge-generating interaction? The case of the biotech cluster in Uppsala, Sweden, Entrepreneurship \& Regional Development, 19(2), pp. $137-159$.

Yin, R. (2009) Case Study Research - Design and Methods, (Thousand Oaks, CA: Sage). 